\title{
The effects of biological and chemical controls on fungal communities colonising tomato (Lycopersicon esculentum Mill.) plants and soil
}

\author{
Bożena Cwalina-Ambroziak ${ }^{1 *}$,Maciej K. Nowak ${ }^{2}$ \\ ${ }^{1}$ Department of Phytopathology and Entomology \\ University of Warmia and Mazury \\ Prawocheńskiego 17, 10-740 Olsztyn, Poland, \\ ${ }^{2}$ Tymbark S.A., Department in Olsztynek \\ Zielona 16, 11-015 Olsztynek, Poland
}

\begin{abstract}
Tomato plants (Rumba Ożarowska cultivar) grown in the greenhouse of the University of Warmia and Mazury in Olsztyn were treated with the biological control agent Polyversum WP, the growth promoter Biochikol 020 PC, the growth regulator Asahi SL, a mycorrhizal inoculum, and the fungicide Bravo 500 SC. Untreated plants served as the control. After fruit harvest, soil, stem and root samples were collected, and fungi were isolated in the laboratory. The applied biological and chemical control agents effectively reduced the abundance of fungi, including pathogenic species, colonising tomato plants and soil. The fungicide Bravo $500 \mathrm{SC}$ showed the highest efficacy. Amongst the biological control agents, Biochikol 020 PC and the mycorrhizal inoculum were most effective in controlling stem colonisation by pathogens, while Polyversum WP offered the best protection of tomato roots and soil.
\end{abstract}

Key words: tomato stems and roots, soil, pathogenic fungi, saprotrophic fungi

\section{INTRODUCTION}

Tomatoes grown in the soil and hydroponically, in the greenhouse and in the open field, can be infested by bacterial pathogens (Xanthomonas campestris pv. vesicatoria, Pseudomonas syringae pv. tomato, Erwinia carotovora subsp. carotovora), funguslike organisms (Phytophthora spp.) and fungi (Alternaria spp., Botrytis cinerea, Cladosporium fulvum, Colletotrichum coccodes, F. oxysporum, F. oxysporum f. sp. radicis-lycopersici, Rhizoctonia solani, Sclerotinia spp., Verticillium spp.) (Gullino and Garibaldi 2001, Tomescu and Negru 2003). Preventive measures include crop rotation, sustainable fertilisation, the maintenance of adequate soil organic matter levels, and seed dressing in ground cultivation (Kokalis-Burelle 2002) as well as soil solarisation, temperature control and adequate ventilation in greenhouse growing (Veloukas et al. 2006). Developing new varieties with improved resistance is also an important consideration (Panthee and Chen 2010). Bacterial and fungal biocontrol agents and biotechnological control agents have become increasingly popular recently. In the greenhouse, powdery mildew on tomato plants has been effectively treated with Trichodex, Biosept 33 SL, Biochikol 020 PC and Tytanit (Cerkauskas et

\footnotetext{
*Corresponding author.

Tel.: +48 89523 41 47; fax: +48 8952336 72;

e-mail: bambr@uwm.edu.pl (B. Cwalina-Ambroziak).
} 
al. 2000, Borkowski and Nowosielski 2001), while Bion $50 \mathrm{WP}$ and Biochikol $020 \mathrm{PC}$ lowered the rates of infection caused by Clavibacter michiganensis subsp. michiganensis (Macias 2002). Fungi of the genus Trichoderma offers protection against grey mould in tomatoes and peppers (Salas-Brenes and Sauchez-Garita 2006). Gliocladium catenulatum strain J1446, isolated from the soil, showed good control efficacy of diseases caused by the following pathogens: Pythium, Phytophthora, Rhizoctonia, Alternaria, Didymella and Botrytis (Niemi and Lahdenpera 2000). The species $T$. harzianum reduced the symptoms of $R$. solani infection in greenhouse tomatoes (Montealegre et al. 2007). Various fungicides (azoxystrobin, cymoxanil, maneb, fenamidone, chlorothalonil) provided effective control of $P$. infestans infection, thus affecting tomato fruit yields (Tofoli et al. 2003). Trifloxystrobin was reported to offer better control of $C$. fulvum infection when applied preventively, not curatively (Veloukas et al. 2006). In a study by Mironova and Marin (2008), tomato plants were sprayed with a mixture of $P$. fluorescens and the fungicide Ridomil Gold MZ 67,8 WG to protect them against $P$. infestans infection, which improved the yield and quality of fruit. Monaco et al. (2009) demonstrated that the use of non-pathogenic isolates of Fusarium, Epicoccum nigrum and T. harzianum might be a viable alternative to fungicides in the control of $B$. cinerea on tomatoes.

The objective of this study was to determine the effects of biological and chemical control agents on the composition of fungal communities colonising tomato plants and soil.

\section{MATERIAL AND METHODS}

Tomatoes of the Rumba Ożarowska cultivar were grown in the greenhouse of the University of Warmia and Mazury in Olsztyn in 2006-2007. Four-week-old tomato seedlings were planted in pots filled with peat substrate and compost soil at a ratio of 1:3. The experiment involved the following treatments: tomato plants sprayed three times with $0.2 \%$ Asahi SL (sodium para-nitrophenolones $0.3 \%$, sodium ortho-nitrophenoles $-0.2 \%$, sodium 5-nitroguaiacolan $-0.1 \%$; $20 \mathrm{ml}$ per plant), plants sprayed three times with $2 \%$ Biochikol 020 PC ( $20 \%$ chitosan; $40 \mathrm{ml}$ per plant), plants sprayed three times with $0.1 \%$ Polyversum WP (oospores of Pythium oligandrum; $40 \mathrm{ml}$ per plant), mycorrhizal inoculum (Glomus spp. - Mycoflor ${ }^{\circledR}$ ) applied to the roots of seedlings prior to planting, tomato plants sprayed twice with Bravo 500 SC (50\% chlorothalonil; according to the recommendations of the Institute of Horticulture in Skierniewice). Every treatment comprised six plants per pot. Pots with unprotected plants served as the control. After fruit harvest, soil, stem and root samples were collected. Following disinfection with 50\% ethanol and $1 \%$ sodium hypochlorite, $0.5 \mathrm{~cm}$ pieces of stems and roots were placed on a PDA medium (five replications). After seven days of incubation, fungal colonies were inoculated onto agar slants for later microscopic identification according to standard keys and monographs. Soil samples collected at a depth of up to $5 \mathrm{~cm}$ under each plant were placed in dishes and mixed with a rotary motion. $1 \mathrm{~g}$ of the resultant fraction was mixed thoroughly with $149 \mathrm{~g}$ fine sand in a flask with a rotary motion for 10 minutes. $300 \mathrm{~mm}^{3}$ of the mixture was poured with a Martin medium $\left(50^{\circ} \mathrm{C}\right)$. Fungal colonies were inoculated onto agar slants for later microscopic identification (Ellis 1971, Skirgiełło et al. 1979, Nelson et al. 1983).

\section{RESULTS AND DISCUSSION}

The most abundant fungal community was isolated from soil samples. A higher number of fungal species were identified in soil samples (36) than in stem and root samples (21 and 18, respectively - Tab. 1). The applied chemical and biological control agents effectively reduced all fungi counts, including pathogenic species, in all analysed environments (tomato stems, roots and soil). The fungicide Bravo $500 \mathrm{SC}$ showed the highest efficacy, but no pathogens were found in soil samples collected in the Polyversum WP treatment, either. The growth regulator Asahi SL contributed to the lowest reduction in the abundance of the causal agents of tomato diseases, as compared with the control treatment. According to reference data (Picard et al. 2000), the development of fungal pathogens and fungus-like organisms can be inhibited by Polyversum WP due to its strong mycoparasitic and competitive abilities. In a study by Patkowska (2006), Polyversum WP and Biosept $33 \mathrm{SL}$ protected the seeds and seedlings of different vegetable species against $A$. alternata, $B$. cinerea, $F$. culmorum, F. oxysporum, F. solani, S. sclerotiorum and $R$. solani. In the present experiment, the predominant pathogens on tomato stems (from $12.5 \%$ in the fungicide treatment to $41 \%$ in the control treatment) were Fusarium species, which colonised tomato plants in all treatments (Fig. 1a). Differences in the abundance of pathogenic fungi, antagonistic, Mucorales and Penicillium 


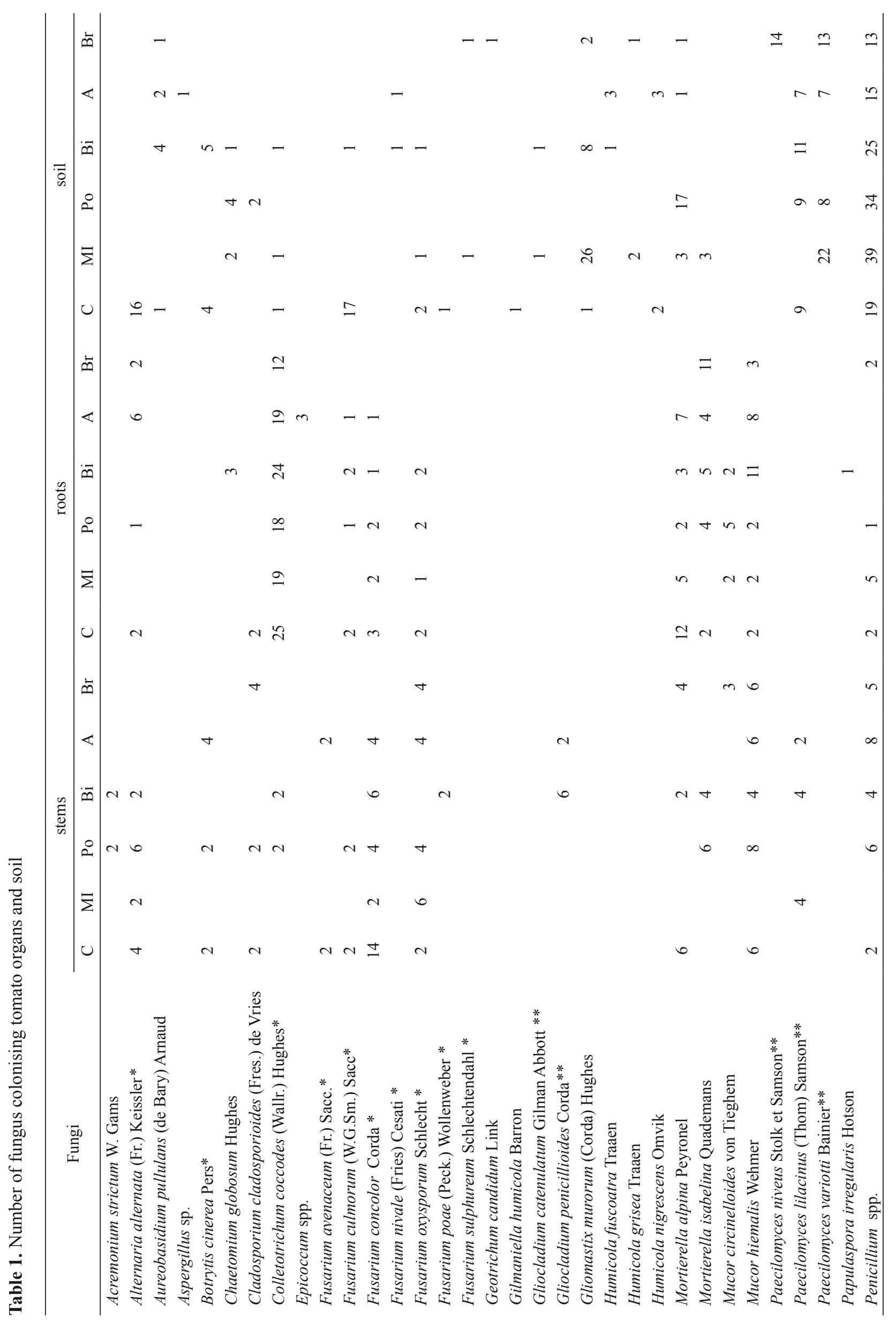




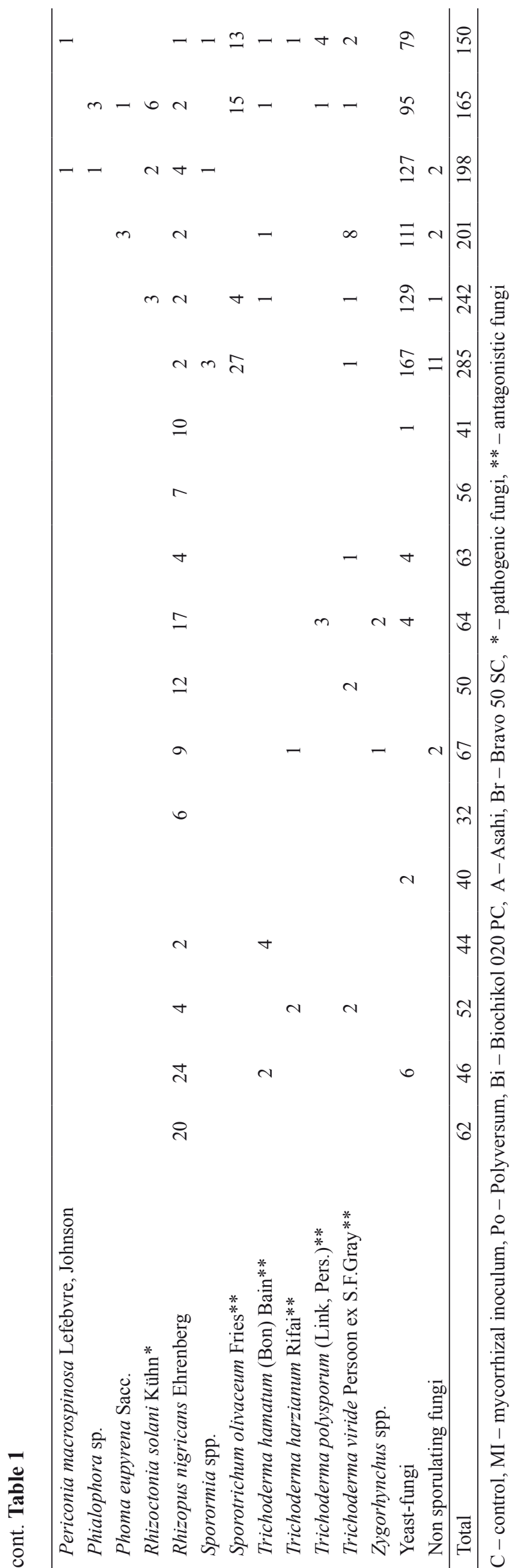

spp. between particular control treatments were significant (Tab. 2). The remaining pathogenic species, A. alternata, B. cinerea and $C$. coccodes, were less abundant on tomato stems. $C$. coccodes attacks tomato leaves, stems, roots and fruits, and disease severity is determined by weather conditions and the age of plant tissue (Byrne et al. 1997).

Pandey (2006) and Minuto et al. (2006) reported that tomato plants could also be infected by $C$. capsici, the causal agent of root rot. Tomato plants sprayed with Bravo 500 SC were least frequently colonised by pathogens. Azoxystrobin applied with Fixade or alone significantly reduced the symptoms of early blight and late blight on tomato plants (Oliveira et al. 2003). As demonstrated by Shashi-Kamal et al. (2007), spraying Lycopersicon esculentum plants with the following fungicides: carbendazim, copper oxychlorite, metalaxyl and mancozeb + tiophanate - methyl, applied alone or in combination, and seed dressing with $T$. harzianum and $P$. fluorescens, lowered the rates of leaf infections caused by Alternaria, Cercospora and Oidium, and fruit infections caused by Colletotrichum and Alternaria. Fungi showing antagonistic activity against pathogens were isolated only from the stems of tomato plants treated with bio-control agents. Species of the order Mucorales had a high share of saprotrophic fungi $(15 \%-60 \%)$.

The most abundant pathogen colonies were found on tomato roots, in particular in unprotected plants. Differences in the abundance of these fungi between particular control treatments were not significant (Tab. 2). The predominant species was $C$. coccodes, the causal agent of anthracnose, whose share ranged from $30 \%$ to $40 \%$ depending on the treatment (Fig. 1b). Fungi of the genus Fusarium were isolated less frequently, and they did not colonise the roots of fungicide-treated plants. Vatchev and Hadjidimitrov (2006) reported that fungicides applied in combination (Ridomil Gold MC 68 WP + Benomyl 50 WP, Previcur 607 $\mathrm{SL}+$ Benomyl $50 \mathrm{WP}$ ) provided better protection against the causal agents of tomato root rot $(F$. oxysporum f. sp. radicis-lycopersici, C. coccodes, $P$. nicotianae, $P$. lycopersici, $R$. solani). In the present study, A. alternata did not colonise the roots of tomato plants treated with mycorrhizal inoculum and plants sprayed with Biochikol 020 PC. According to Ait-Barka et al. (2004), Biochikol induces morphological and structural changes in fungal cells, thus inhibiting the growth of pathogens. Pięta et al. (2006) and Kurzawińska (2007) both highlighted the significant role played by Biochikol 

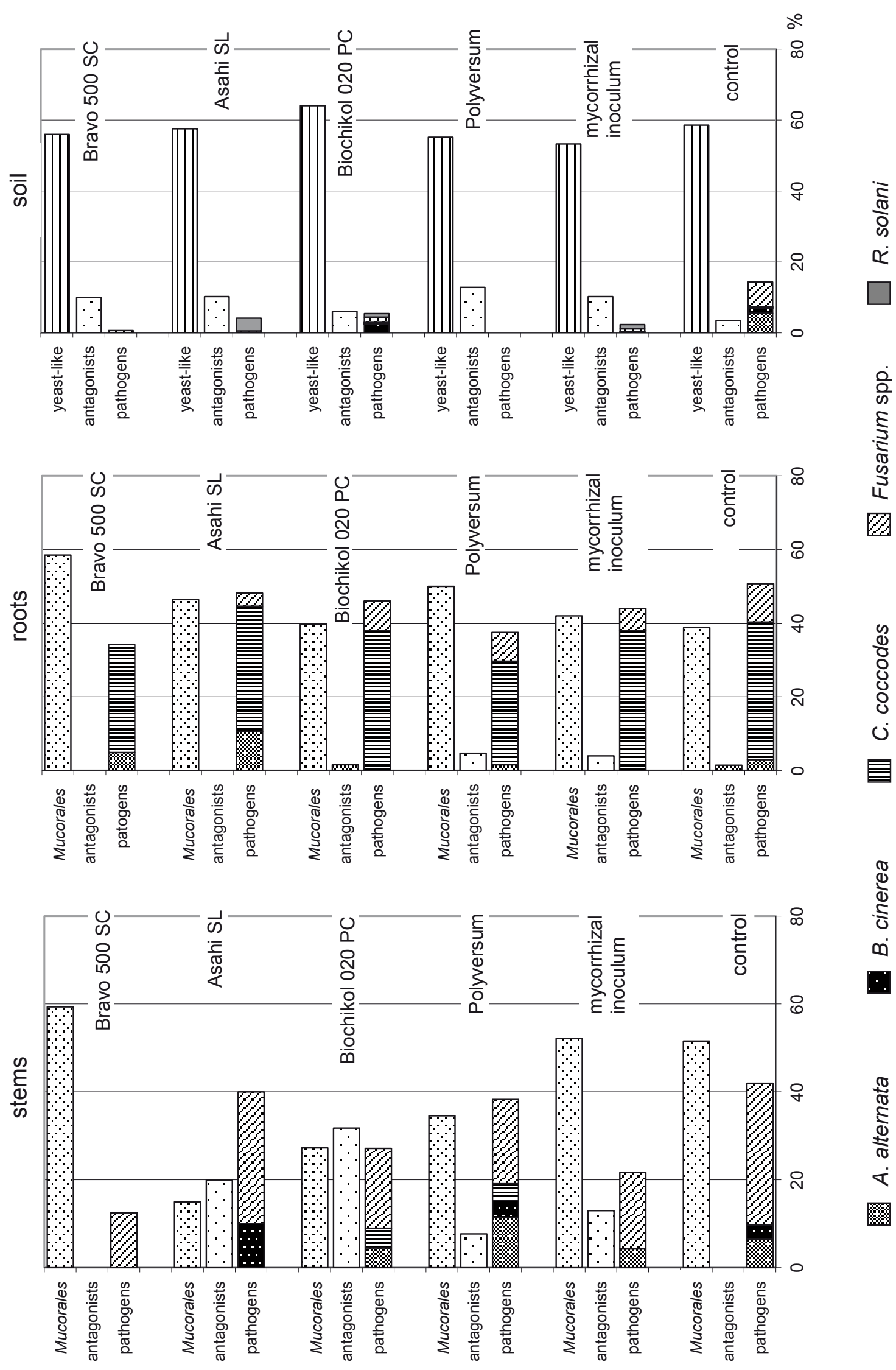
Table 2. Most frequently isolated fungi from tomato organs and soil (mean numbers of isolates for years)

\begin{tabular}{lcccccccccccc}
\hline \multirow{2}{*}{ Treatments } & \multicolumn{4}{c}{ Stems } & \multicolumn{4}{c}{ Roots } & \multicolumn{4}{c}{ Soil } \\
\cline { 2 - 12 } & Path & Antag & Muc & Pen & Path & Antag & Muc & Pen & Path & Antag & Muc & Pen \\
\hline Control & $13.0 \mathrm{a}^{*}$ & $0.0 \mathrm{c}$ & $16.0 \mathrm{a}$ & $1.0 \mathrm{bc}$ & $17.0 \mathrm{a}$ & $0.5 \mathrm{a}$ & $13.0 \mathrm{a}$ & $1.0 \mathrm{a}$ & $20.5 \mathrm{a}$ & $5.0 \mathrm{~b}$ & $1.0 \mathrm{a}$ & $9.5 \mathrm{a}$ \\
MI & $5.0 \mathrm{c}$ & $3.0 \mathrm{~b}$ & $12.0 \mathrm{ab}$ & $0.0 \mathrm{c}$ & $11.0 \mathrm{a}$ & $1.0 \mathrm{a}$ & $10.5 \mathrm{a}$ & $2.5 \mathrm{a}$ & $3.0 \mathrm{~b}$ & $12.5 \mathrm{ab}$ & $4.0 \mathrm{a}$ & $19.5 \mathrm{a}$ \\
Polyversum & $10.0 \mathrm{ab}$ & $2.0 \mathrm{bc}$ & $9.0 \mathrm{~b}$ & $3.0 \mathrm{ab}$ & $12.0 \mathrm{a}$ & $1.5 \mathrm{a}$ & $16.0 \mathrm{a}$ & $0.5 \mathrm{a}$ & $0.0 \mathrm{~b}$ & $13.0 \mathrm{ab}$ & $9.5 \mathrm{a}$ & $17.0 \mathrm{a}$ \\
Biochikol 020 PC & $6.0 \mathrm{abc}$ & $7.0 \mathrm{a}$ & $6.0 \mathrm{bc}$ & $2.0 \mathrm{abc}$ & $14.5 \mathrm{a}$ & $0.5 \mathrm{a}$ & $12.5 \mathrm{a}$ & $0.0 \mathrm{a}$ & $5.5 \mathrm{~b}$ & $6.0 \mathrm{ab}$ & $2.0 \mathrm{a}$ & $12.5 \mathrm{a}$ \\
Asahi SL & $7.0 \mathrm{abc}$ & $2.0 \mathrm{bc}$ & $3.0 \mathrm{c}$ & $4.0 \mathrm{a}$ & $13.5 \mathrm{a}$ & $0.0 \mathrm{a}$ & $13.0 \mathrm{a}$ & $0.0 \mathrm{a}$ & $3.5 \mathrm{~b}$ & $8.5 \mathrm{ab}$ & $1.5 \mathrm{a}$ & $7.5 \mathrm{a}$ \\
Bravo 500 SC & $2.0 \mathrm{c}$ & $0.0 \mathrm{c}$ & $9.5 \mathrm{~b}$ & $2.5 \mathrm{abc}$ & $7.0 \mathrm{a}$ & $0.0 \mathrm{a}$ & $12.0 \mathrm{a}$ & $1.0 \mathrm{a}$ & $0.5 \mathrm{~b}$ & $17.5 \mathrm{a}$ & $8.0 \mathrm{a}$ & $6.5 \mathrm{a}$ \\
\hline
\end{tabular}

Path - pathogens, Antag - antagonists, Muc - Mucorales, Pen - Penicillium spp., MI - mycorrhizal inoculum

*Means with the same letter do not differ significantly (Duncan test, $\mathrm{p}=0.01$ )

$020 \mathrm{PC}$ in disease control in vegetables. In this experiment, species of the order Mucorales were isolated most frequently. Antagonistic Trichoderma species were much less abundant, as they did not colonise the roots of tomato plants sprayed with the growth regulator Asahi SL and the fungicide Bravo 500 SC.

The soil fungal community was dominated by yeast-like fungi, which accounted for $53.3 \%$ and $64 \%$ of all isolates in the treatments with mycorrhizal inoculum and Biochikol 020 PC, respectively (Fig. 1c). The desirable antagonistic species of the genera Paecilomyces and Trichoderma were isolated in greatest abundance from soil samples collected in the Polyversum treatment, where no pathogens were found. Those beneficial fungal species were present at very low numbers in the control treatment. The abundance of pathogenic fungi and $R$. solani was substantially lower in experimental treatments than in the control. Polyversum provided an effective control of the infection caused by $F$. oxysporum f. sp. radicis-lycopersici (Benhamou et al. 1997). The findings of other researchers (Catxarrera et al. 2002, Barakat and Al-Masri 2009) also show that an increase in the population size of Trichoderma asperellum due to the application of organic fertilisers inhibited $F$. oxysporum infection in tomato plants. Mycorrhizal inoculum (Glomus fasciculata) decreased the severity of $P$. aphidermatum infection and increased fruit yield (Reddy et al. 2006).

\section{CONCLUSIONS}

1. The following fungal pathogens were isolated from tomato stems, roots and soil: A. alternata, B. cinerea, C. coccodes, Fusarium species and R. solani.

2. The applied biological and chemical control agents effectively reduced the abundance of fungi, including pathogenic species, colonising tomato plants and soil.

3. Unprotected tomato plants were abundantly colonised by pathogens. The fungicide Bravo $500 \mathrm{SC}$ showed the highest efficacy in reducing the population size of pathogenic fungi.

4. The soil communities of yeast-like fungi were most abundant in all treatments. Pathogens were not found in soil samples collected in the Polyversum WP treatment, where antagonistic fungi were predominant.

\section{REFERENCES}

Ait Barka E., Eullaffroy P., Clement C., Vernet G., 2004. Chitosan improves development, and protects Vitis vinifera L. against Botrytis cinerea. Plant Cell. Rep. 22: 608-614.

Barakat R. M., Al.-Masri M.L., 2009. Trichoderma harzianum in combination with sheep manure amendment enhances soil suppressiveness of Fusarium wilt of tomato. Phytopathol. Mediterranea 48(3): 385-395.

Benhamou N., Rey P., Cherif M., Hockenhull J., Trilly J., 1997. Treatment with the mycoparasite Pythium oligandrum triggers induction of defenserelated reactions in tomato roots when challenged with Fusarium oxysporum f. sp. radicis-lycopersici. Phytopathology 87: 108-122.

Borkowski J., Nowosielski O., 2001. The use of Trichodex 25 WP, Biosept 33 SL, Chitosan and Florochron in the protection of tomato against powdery mildew. The effect of these preparations on the fruit yield. Bull. Pol. Acad. Sc. Biol. Sci. 49(3): 173-178.

Byrne J.M., Hausbeck M.K., Hammerschmidt R., 1997. Conidial germination and aspersorium formation of Colletotrichum coccodes on tomato foliage. Plant Dis. 81: 715-718.

Catxarrera L., Trillas-Gay M.I., Steinberg C., Alabouvette C., 2002. Use of sewage sludge compost and Trichoderma asperellum isolates to suppress 
Fusarium wilt of tomato. Soil Biol. Biochem. 34(4): 467-476.

Cercauskas R.F., Leopold L., Ferguson G., 2000. Control of powdery mildew in greenhouse cucumber, peppers and tomatoes. Phytopathology 90: 812.

ELLIS M.B., 1971. Dematiaceus hyphomycetes. Commonwealth Mycological Institute Kew Surrey, England.

Gullino M.L., Garibaldi A., 2001. Recognizing and fighting fungal diseases of tomatoes. Colture Protette 30(2): 23-29.

KoKalis-Burelle N., 2002. Biological control of tomato diseases. Books in Soil, Plants and the Environment. Biological control of crop diseases: 225-262.

KuRZAwińsKa H., 2007. Potential use of chitosan in the control of lettuce pathogens. Polish Chitin Society, Monograph XII: 173-178.

Macias W., 2002. Skuteczność biologiczna wybranych środków ochrony roślin w ochronie pomidora przed rakiem bakteryjnym (Clavibacter michiganensis subsp. michiganensis). Prog. Plant Protection / Post. Ochr. Roślin 42(2): 793-796.

MinutoA., Gilardi G., GaribaldiA., 2006. Colletotrichum capsici: a soilborne pathogen potentially dangerous of grafted tomatoes. Informatore Fitopatologico 56(9): 26-30.

Mironova E.V., Marin G.S., 2008. Biological products in tomato cultivation. Zaschita i Karantin Rastenii. 2: 47.

Monaco C., Dal Bello G., Rollaw M.C., Ronco L., Lampugnami G., Arteta N., Abramoff C., Aprea A., Larran S., Stocco M., 2009. Botrytis cinerea on tomato using naturally occurring fungal antagonists. Archiv. Phytopath. Plant Protec. 42(8): 729-737.

Montealegre J., Valderrama L., Herrera R., Besoain X., PÉrez L.M., 2007. Bio-control of Rhizoctonia solani in tomatoes with Trichoderma harzianum mutants. IOBC/WPRS Bulletin, 2007, 30, 6: 153-157.

Nelson P.E., Toussoun T.A., Marasas W.F.O., 1983. Fusarium species. The Pensylvania State University Press, University Park and London.

Niemi M., LahdenPera M.L., 2000. Gliocladium catenulatum J 1446 - a new biofungicide for horticultural crops. DJF Rapport, Havebrug 12: 81-88.

Oliveira S.H.F., Sinigaglia C., Garcia JR O., 2003. Effects of fungicide adjuvants to control late blight (Alternaria solani) and early blight (Phytophthora infestans) in potato and tomato. Revista Agricult. 78(1): 57-66.

PANDEY K.K., 2006. Colletotrichum capsici: a new fruit rot pathogen of tomato in Utar Pradesh. J. Mycol. Plant Pathology 36(1): 104-105.

Panthee, D.R., Chen F., 2010. Genomics of fungal disease resistance in tomato. Current Genomics 11(1): 30-39.
PATKOWSKA E., 2006. Effectiveness of grapefruit extract and Pythium oligandrum in the control of bean peas pathogens. J. Plant Protec. Res. 46(1): 15-28.

Picard K., Popchet M., Blein J.P., Rey P., Trilly Y., Benhamou N., 2000. Oligandrin A proteinaceous molecule produced by the mycoparasite Pythium oligandrum induces resistence to Pythium parasiticum infection in tomato plants. Plant Physiol. 124: 379-395.

Pięta D., Patkowska E., Pastucha A., 2006. Influence of Biochikol 020 PC used as seed dressing of bean on healthiness and yield of plants. Polish Chitin Society, Monograph XI: 159-170.

Reddy B.N., Raghavender C.R., Sreevani A., 2006. Approach for enhancing mycorrhiza - mediated disease resistance of tomato damping-off. Ind. Phytopathol. 59(3): 299-304.

Salas-Brenes W., Sauchez-Garita V., 2006. Biological control of Botrytis cinerea on pepper and tomato crops under greenhouse conditions. Manejo Integrado de Plagas Agroecologia 78: 56-62.

Shashi-Kamal, Rajkumar, Raghav M., Singh R.V., 2007. Field efficacy of bioagents and fungicides against tomato (Lycpersicum esculentum Mill.) diseases. Environment and Ecology 25 (Special 3 A): 921-924.

Skirgielto A., Zadara M., Ławrynowicz M., 1979. Grzyby (Mycota). 10. Glonowce (Phycomycetes). Pleśniakowe (Mucorales). PAN Instytut Botaniki, Warszawa-Kraków.

Tofoli J.G., Dominques R.J., Garcia-Junior O., 2003. Tomato late blight control by fungicides and their effects on yield. Arquives. Inst. Biolog. Sao Paulo 70(4): 473-482.

Tomescu A., Negru G., 2003. An overview on fungal diseases and pests on the field tomato crops in Romania. Acta Hort. 613: 259-266.

Vatchev T., Hadjidimitrov B., 2006. Application of fungicides to control crown and root rot disease complex of greenhouse-grown tomatoes. Rastenievdni Nauki, 43(4): 331-339.

Veloukas T., Bardas G.A., Karaoglanidis G.S., Tzavella-Klonari K., 2006. Protective, curative and eradicant of the strobilurin fungicide trifloxystrobin against Cladosporium fulvum Cooke on tomato. Proc. $12^{\text {th }}$ Mediterranean Phytopathological Congress, 1115 June, Rhodes, Greece: 448-450.

\section{WPLYW OCHRONY BIOLOGICZNEJ I CHEMICZNEJ NA ZBIOROWISKO GRZYBÓW KOLONIZUJACCYCH ORGANY POMIDORA (LYCOPERSICON ESCULENTUM MILL.) I GLEBE}

Streszczenie: Pomidor odmiany Rumba Ożarowska uprawiano w szklarni Uniwersytetu WarmińskoMazurskiego w Olsztynie. W ochronie pomidora stosowano: preparat biologiczny Polyversum WP, 
biotechniczny Biochikol 020 PC, regulator wzrostu Asahi SL, szczepionkę mikoryzową, fungicyd Bravo 500 SC (kontrola - rośliny niechronione). Po zbiorze owoców pobierano próby gleby, łodygi oraz korzenie w celu izolacji grzybów w laboratorium.

Zastosowana ochrona biologiczna i chemiczna ograniczały liczebność grzybów, w tym patogenów, zasiedlających organy pomidora i glebę spod uprawy. Największą skuteczność wykazał fungicyd Bravo 500 SC. Spośród elementów biologicznej ochrony Biochikol 020 PC i szczepionka mikoryzowa najbardziej ograniczały liczebność patogenów zasiedlających łodygi, a Polyversum WP - korzenie i glebę.

Received April 12, 2011; accepted March 20, 2012 